DOI:

\title{
SURELERIN BELIRLI DÖNEMLERE VE OLAYLARA İÂFESI*
}

\section{Burhan ÇONKOR **}

Öz

Bu makalede özellikle son dönemde Kur'ân surelerini dönemlere göre tasnif eden dört araştırmacı ve ilgili çalışmaları ele alınmıştır. Bu çalışmalarda Mekkî sureler; nüzul rivayetleri, surelerin üslup ve içerikleri dikkate alınarak dönemlere ayrılmış, aynı zamanda sureler, bu dönemlerde cereyan eden olaylarla da ilişkilendirilmiştir. Yine bu makalede, ilgili çalışmalarda kullanılan yöntemler ve elde edilen sonuçlar üzerinde durulmuş, ictihada dayalı bu türden tasniflerde ortak sonuçlara ulaşılmasının imkânı sorgulanmıştır. Ancak bu çalışma, herkes tarafından kabul edilebilecek bir sure tertibinin mümkün olmayışı yanında, belki de bu imkânsızlığın bir sonucu olarak ortaya çıkan dönemsel tasnif çalışmalarında da ortak bir sonuca ulaşılamayacağını göstermektedir.

Anahtar Kelimeler: Kur’ân, Mekkî, Sure, Kronoloji, Nüzul, Tertîb

\begin{abstract}
The Association of Surahs to Certain Time Periods and Events

Efforts to understand the Quran has continued uninterrupted since its revelation period and the interpretation activity has been carried out using certain methods until today. There are three different approaches to the interpretation of the Qur'an. Firstly, commentaries that are written according to the composition of Companion Osman's mushaf; secondly, commentaries that are based on a subject that do not take this into account; the third one is the interpretation made by organizing the verses according to the time of revelation. Identifying the order of revelation and making the interpretation in accordance with this order is also used as a method. For this purpose, researchers
\end{abstract}

- Bu makale, Boykotun Bitiminden Hicrete Kadar Olan Dönemde İnen Surelerin Tahlili isimli Doktora tezimizden üretilmiştir. (Danışman: Prof. Dr. Halis Albayrak, Ankara Üniversitesi Sosyal Bilimler Enstitüsü, Ankara 2015.)

*- Dr., Çankırı İl Müftülügüü, bconkor@hotmail.com 


\section{0 •SURELERIN BELIRLİ DÖNEMLERE VE OLAYLARA İZÂFESİ}

have benefited from knowledge of asbab al-nuzul and Meccan-medinan verses. On the other hand, the thought that the verses cannot be identified according to chronological order, has led the researchers to classify the verses according to specific periods and make comments based on the events of that period. These studies sometimes have encompassed the whole peroid and sometimes in-depth studies conducted on the time period of certain ranges.

This article discusses the work of four recent researchers who classified Qur'an surahs according to time periods. These studies have classified surahs according to narrations about their time of revelation and the style and content of the surahs. They also associated the surahs with the events that took place in this period. Additionally this article focuses on the methods used and the results obtained in these relevant works and questions the possibility of achieving common results in such kind classifications that are based on ijtihad. However, due to the impossibility of a time classification of surahs that is accepted by everyone, this paper also shows the impossibility of reaching a common conclusion in the studies on periodic classification of surahs.

Keywords: Quran, Meccan, Surah, chronology, revelation, arrangement of surahs.

\section{GİRIŞ}

Kur'ân tefsirine yönelik çalışmalarda, sure ve ayetlerin indiği zamanın ve nüzul sırasının dikkate alınmaması vakıaya uygun olmayan sonuçların ortaya çıkmasına sebep olmaktadır. İndiği dönemin olaylarına ve yaşanan problemlere ilahi cevaplar içeren sure ve ayetlerin, bağlamlarından kopartılarak doğru anlaşılması zordur. Bu nedenle surelerin indiği dönemlerin tespit edilmesine ve buna göre yorumlar geliştirilmesine yönelik olan kronolojik çalışmalar ortaya çıkmaya başlamıştır.

Surelerin nüzul sırasına göre tefsir edilmesine yönelik ilk çalışmalar ve 'kronolojik okuma' tabiri, ilk defa XIX. yüzyılda müsteşrikler tarafından gündeme getirilmiştir. Bu çalışmaların, müsteşriklerin Kur'ân'ın Hz. Muhammed'e ait olduğu düşünceleri ve onun düşüncelerini anlamaya çalışmaları sonucunda ortaya çıktığı ifade edilmiştir. ${ }^{1}$ Kur’ân üzerine araştırma yapan Batılılar, rivayetlerden ziyade, ayet ve surelerin hitap, üslup ve konularına bakarak indiği dönem ve bağlı olduğu olayları izah etmeye çalış-

1 Bu konuda detaylı bilgi için bkz. Fethi Ahmet Polat, Çăgdaş İslam Düşüncesinde Kur'ân'a Yaklaşımlar, İz yay. İstanbul, 2008, s. 363; Yaşar Kurt, “Kur'ân'ın Nüzûl Süreci ve Nüzûl Sırasını Esas Alan Tefsir Üzerine”, OMÜ. Illahiyat Fakültesi Dergisi, 2012, say1, 33, s. 28. 
mışlar ve bu doğrultuda kendilerine göre sure tertipleri oluşturmuşlardır. Bunun kasıtlı bir amaç için ortaya atıldığı iddiası ve oryantalistlerin bazı ayet ve sureleri bu sıralamada vahiy öncesine yerleştirerek Hz. Peygamber'in kendi yazdığına dair iddiaları, çağdaş Müslüman müfessirlerin bu türden çalışmalara temkinli yaklaşmasına sebep olmuştur.

Müslüman araştırmacılar, nüzul sırası ve surelerin indiği ortamın dikkate alınarak Kur'ân'ın tefsir edilmesini, Kur'ân metninin yetersiz görülmesi gibi bir algıya sebep olduğu gerekçesiyle (Sipahioğlu 2014: 16) pek tasvip etmemişlerdir. Batı'da ise surelerin nüzul sırasına göre tertip edilmesi konusunda bir takım çalışmalar yapılmış ve bu konuda öne çıkan isimler ${ }^{2}$ olmuştur. Bu isimler, Kur'ân kronolojisi konusunda müstakil eserler kaleme almışlar ve her biri kendisine ait bir sure tertibi veya dönemsel sure tasnifi yapmıştır. ${ }^{3}$

İslam dünyasında kronoloji konusuna temkinli yaklaşılsa da özellikle son yüzyıl içerisinde bu türden çalışmalar yapılmıştır. ${ }^{4} \mathrm{Bu}$ çalışmalarda genellikle bilinen nüzul sıralamas $1^{5}$ dikkate alınmış olmasına rağmen, bir takım

2 Gustav Weil (ö. 1889), Sir William Muir (ö. 1905), Theodor Nöldeke (ö. 1930), Richard Bell (ö. 1952), Hartwig Hirschfeld (ö. 1954), Régis Blachère (ö. 1973), William Montgomery Watt (ö. 2006).

3 Batılı araştırmacıların ortaya koyduğu dönemsel sure tasnifleri ve bu konuda ortaya koydukları çalışmaları hakkında detaylı bilgi için bkz. İsmail Albayrak, "Kur'ân Âyetlerinin Tertibi Hakkındaki Oryantalist Söyleme Genel Bir Bakış", Marife, 2/3 (2002), s. 155-164; Esra Gözeler, "Kur'ân Ayetlerinin Târihlendirilmesine Batılı Yaklaşımlar", AÜIF Dergisi, 2010, Cilt: LI sayı, 2, s. 299-316; Abdülvahid Yakub Sipahioğlu, Boykot Döneminde Nazil Olan Surelerin Tespiti Ve Değerlendirilmesi, (Yüksek Lisans), Ankara Üniversitesi Sosyal Bilimler Enstitüsü, Ankara, 2014, s. 16 vd.

4 İslam dünyasında yapılan kronolojik sure tertibi çalışmaları için bkz. Burhan Çonkor, Boykotun Bitiminden Hicrete Kadar Olan Dönemde İnen Surelerin Tahlili, (Doktora), Ankara Üniversitesi Sosyal Bilimler Enstitüsü, Ankara, 2015, s. $58 \mathrm{vd}$.

5 Kaynaklarımızda Hz. Osman'a dayandırılan ve İslamî gelenekte kabul görmüş bir nüzul sıralaması yer almaktadır. Özellikle Mekke döneminde ilk ve son nâzil olan sure konusundaki ihtilaflar nedeniyle, bir takım farklılıklarla kaynaklarımızda zikredilmektedir. İlgili sıralama için bkz. Ebû Bekr Ahmed b. Ali el-Beyhakî, Delâilü'n-Nübüvve ve Ma'rifetü Ahvâli Sâhibi'ş-Şerî'a, Beyrut, 1405, VII/142143; Alâuddîn Ali b. Muhammed b. İbrâhîm el-Hâzin, Lübâbü̈'t-Te'vîl fi Meâni 'tTenzîl, Dâru'l-Kütübi'l-İlmiyye, Beyrut, 1415, I/9-10; Bedreddîn Muhammed b. Abdullah ez-Zerkeșî, el-Burhân fî Ulûmi'l-Kur'ân, Thk. Muhammed Ebû'l-Fadl İbrâhîm, Dâru'l-Ma'rife, Beyrut, 1957, I/193-194; Ebu'l-Fadl Celâlüddîn Abdurrrahman es-Suyûtî, el-îtkân fì Ulûmi'l-Kur'ân, Thk. Muhammed Ebû'l-Fadl 
gerekçelerle, ilgili sıralamada değişiklik yapıldığı da olmuştur. Yine bu çalışmaların bazılarında sureler, nüzul sırasına göre tefsir edilmesinin yanında, özellikle Mekkî sureler belirli dönemlere göre de tasnif edilmiş ve bu dönemler ile dönem içerisinde yaşanan olaylar paralelinde yorumlar geliştirilmiştir. Medine dönemine ait rivayetler, bu dönem surelerin nüzul zamanını daha net tespit etme imkânı sunduğundan, Medenî sureler daha çok yıllara veya içerdiği konulara göre tasnif edilmiştir. Bizim bu makalede üzerinde duracağ1mız çalışmalar da sureleri bu şekilde dönemlere göre tasnif eden Müslüman araştırmacıları ve yaptıkları çalışmaları kapsamaktadır.

\section{SURELERİ DÖNEMLERE GÖRE TASNIF EDEN ARAŞTIRMACILAR}

Surelerin dönemlere göre tasnif edilmesine yönelik, ilk dönemlere ait İslamî kaynaklarda bir çalışmaya rastlamak oldukça zordur. ${ }^{6}$ Zerkeşî’nin el-Burhân isimli kitabında, Ebû'l-Kasım en-Neysâbûrî'nin (ö. 406/1015) etTenbîh alâ fadli ulûmi'l-Kur'ân adlı eserinde bu şekilde bir çalışma yapılmasının gerekliliğine işaret ettiği rivayet edilmektedir. İlgili rivayet şöyledir: “Kur'ân'ın nüzulünü, nüzul şeklini ve yerini, Mekke ve Medine döneminin başlarında, ortalarında ve sonlarında nâzil olanların sıralarını... bilmek, Kur'ân ilimlerinin en şereflilerindendir." (Zerkeşî 1957: I/192; Suyûtî 1974: I/36; Sâlih 2000: 169). Bu tanımda, Neysâbûrî' nin Mekke ve Medine dönemini başlangıç, orta ve son bölüm olmak üzere üçe ayırdığını görmekteyiz. Bu yaklaşım, Batılı araştırmacıların yaptığı tasnife benzemekte ise de, örnek bir çalışmasının olup olmadığını bilemiyoruz.

Genel kabul gören nüzul tertibi dışında, surelerin belli dönemlere ayrılarak tasnif edilmesine yönelik çalışmalarda iki açıdan farklar göze çarpmaktadir.

Birincisi, dönemlerin ayırımı konusundaki farktır. Araştırmacılar dönemleri belirlerken, dönemin önemli olaylarını ve kırılma noktalarını dikkate

İbrâhîm, Dâru'l-Ma'rife, Beyrut, 1974, I/37-41;İsmail Cerrahoğlu, Tefsir Usulü, TDV. Yay, Ankara, 1998, s. 79-88.

6 Usül kitaplarımızda önemli bir yer tutan, nesh, esbâb-ı nüzul ve Mekkî-Medenî gibi konular, ilk dönemlerden beri Kur'ân'ın tarihî bağlamının dikkate alınarak anlaşılmaya çalışıldığının bir göstergesi olabilir. Günümüzde ise klasik tefsir bazı yönlerden eleştirilmiş, yetersiz olduğuna dair görüşler ortaya atılmıştır. Bu görüşlerin neler olduğu ve tutarlılıklarına dair değerlendirmeler için bkz. Polat, a.g.e. s. $33 \mathrm{vd}$. 
aldıkları için, kendilerine göre daha belirleyici gördükleri olayları, yeni bir dönemin başlangıcı kabul etmişlerdir. Bu bakış açısı neticesinde araştırmacılar Mekke yıllarını dönemlere ayırmış ve her döneme belli sureleri yerleştirmiştir. Medine dönemi sureleri ise daha çok yıllar veya konular esas alınarak tasnif edilmiştir.

İkincisi ise bu dönemlere yerleştirilen sure sayısı ile bu surelerin kendi içlerindeki sıralamalarında görülen farklılıktır. Netice itibariyle bu farklılıklar, araştırmacıların, surenin hitap şekli veya konuları ile olaylar arasındaki bağlantılardan hareketle oluşturdukları yorum farklılıklarından kaynaklanmaktadır.

Çalışmamızda sureleri dönemlere göre tasnif eden çalışmalar hakkında bilgi verdikten sonra bu çalışmalar arasındaki yöntem ve sonuçlar açısından farklılıklara yer vereceğiz.

\section{1. Ömer Rıza Doğrul}

Ülkemizde, surelerin dönemlere göre tasnif edildiği ilk çalışmalardan biri Ömer Rıza Doğrul'un ${ }^{7}$ hazırladığı, Tanrı Buyruğ $u^{8}$ adlı meal ve tefsirdir. $\mathrm{Bu}$ eserde Mekkî sureler ilk, orta ve son dönem olarak üçe ayrılmış, Medine dönemindeki sureler de yıllara göre gruplandırılmıştır. Yine bu eserde, her surenin girişinde, o surenin nüzul tarihi ve konuları hakkında bilgi verilmiş, daha sonra sureler kendi içerisinde, içerdiği konulara göre bölümlere ayrılmış

7 Ömer Rıza Doğrul, aslen Burdur'lu olup Mısır'a yerleşmiş bir ailenin çocuğu olarak 1893'te Kahire'de doğmuştur. Tahsilini Ezher Üniversitesi'nde tamamlamıştır. Eserlerinin arasında özellikle Tanrı Buyruğu adlı tefsiri önemli bir yere sahiptir. Te'lif ve tercüme birçok esere imza atan ve çeşitli gazete ve dergilerde çok sayıda makale ve yazısı bulunan Ömer Rıza Doğrul, 13 Mart 1952 yılında İstanbul'da vefat etmiş olup, Edirnekapı şehitliğinde medfundur. Hayatı, eserleri ve kendisine yöneltilen eleştirilerle ilgili geniş bilgi için bkz. Mustafa Uzun, "Doğrul, Ömer Rıza”, DİA, IX/489; Ali Akpınar, “Çok Yönlü Bir Kişilik Olarak Ömer Riza Doğrul (1893-1952)”, I. Burdur Sempozyumu, Burdur, 2007, s. 439447.

8 Tanrı Buyruğu adlı eserin mukaddimesinde Kur'ân'ın tanımı, taksim ve tertibi, isimleri, sureleri, ayetleriyle dinin esasları hakkında kısa bilgiler verilmiş, $\mathrm{Hz}$. Peygamber'in sîretinin kronolojik tablosu kaydedilmiş, sonuna fihrist ve indeks eklenmiştir. Tanrı Buyruğu'nun mukaddimesi, Kur'ân ve İslâm Üzerine adıyla kitap halinde de basılmış̧ır. Ayrıca eserle ilgili olarak Rukiye Öner (Kuloğlu) tarafindan Ömer Rıza Doğrul'un Hayatı, Eserleri ve "Tanrı Buyruğu" Adlı Tefsîri başlıklı bir yüksek lisans tezi hazırlamıştır. (Bkz. Ali Akpınar,"Tanrı Buyruğu”, $D \dot{I} A$, XXXIX/ 571-572). 
ve her bölüme konusuna göre farklı başlıklar verilmiştir. Sureler mushaftaki sırasına göre tefsir edilmiş, giriş kısmında surenin muhtemel iniş tarihi hakkında da değerlendirmeler yapılmıştır. Nüzul zamanına dair değerlendirmeler yapılırken genellikle surelerin birbiri ile olan bağlantılarına vurgu yapılmış ve arka arkaya indiği tahmin edilen iki sure arasında konu devamının olduğuna dikkat çekilmiştir. Ömer Rıza Doğrul'un bir diğer farklı değerlendirmesi de surelerin indiği yere ve döneme dair tespitlerde bulunmasıdır. Örneğin Medine devrinde indiği kesin olan ve açıklamalarını da bu doğrultuda yaptığ bazı surelerin başlığına, indiği yeri dikkate alarak 'Mekke'de nâzil olmuştur' ifadesini kullanmıştır. Dikkat edilmediği takdirde Medine döneminde inen bir sure Mekke döneminde inmiş gibi anlaşllabilmektedir. Hâlbuki ilgili sureler hicretten sonra fakat Mekke sınırları dâhilinde inmiştir. Ömer Rıza Doğrul, surelerin kronolojik olarak sıralanmasının, sureler içerisinde farklı dönemlere ait ayet gruplarının bulunması nedeniyle, imkânsız olduğunu söylemektedir. Ona göre ancak, surelerin belli bir döneme ait olduğu söylenebilir. (Doğrul 1980: XLVII). Bu doğrultuda eserinin giriş kısmında yaptığı dönemlere göre sure tasnifi ve nüzul sıralaması şu şekildedir:

\section{Mekkî sureler:}

a) Mekke devrinin ilk bölümünde, yani risaletin ilk 5 yılında inen sureler:

Alak-96, (1-5), Fâtiha-1, İsrâ-17, Kehf-18, Meryem-19, Tâhâ-20, Enbiyâ-21, Kâf-50, Zâriyât-51, Tûr-52, Necm-53, Kamer-54, Rahmân-55, Vâkıa- 56, Mülk-67, Kalem-68, Hâkka-69, Meâric-70, Nûh-71, Cin-72, Müzzemmil-73, Müddessir-74, Kıyâme-75, İnsân-76, Mürselât-77, Nebe'78, Nâziât-79, Abese-80, Tekvîr-81, İnfitâr-82, Mutaffifîn-83, İnşikâk-84, Bürûc-85, Târık-86, A'lâ-87, Ğâşiye-88, Fecr-89, Beled-90, Şems-91, Leyl92, Duhâ-93, İnşirâh-94, Tîn-95, Alak-96, Kadr-97, Beyyine-98, Zilzâl-99, Adiyât-100, Kâria-101, Tekâsür-102, Asr-103, Hümeze-104, Fîl-105, Kureyş-106, Mâûn-107, Kevser-108, Kâfirûn-109, Mesed-111, İhlâs-112, Felâk-113, Nâs-114.

b) Mekke devrinin orta bölümünde yani risaletin 5. ve 10. seneleri arasında inen sureler:

Ankebût-29, Rûm-30, Lokmân-31, Secde-32, Sebe'-34, Fâtır-35, Yâsîn-36, Sâffât-37, Sâd-38, Zümer-39, Mü'min-40, Fussilet-41 (veya 
Secde), Şûra-42, Zuhruf-43, Duhân-44, Câsiye-45, Ahkâf-46.

c) Mekke devrinin son bölümünde yani son 3 yılında inen sureler:

En'âm-6, A'râf-7, Yûnus-10, Hûd-11, Yûsuf-12, Ra'd-13, İbrâhîm-14, Hicr-15, Nahl-16, Hac-22, Mü'minûn-23, Furkân-25, Şuarâ-26, Neml-27, Kasas-28.

\section{Medenî sureler:}

a) Medine devrinin ilk iki senesi yani hicretin birinci ve ikinci senesi nâzil olan sureler: Bakara-2, Enfâl-8, Muhammed-47, Saff-61, Cum'a-62, Teğâbun-64.

b) Hicretin üçüncü ve dördüncü yıllarında üç sure nâzil olmuştur. Bunlar: Âl-i İmrân-3, Mücâdele-58, Haşr-59.

c) Hicretin beşinci ile sekizinci seneleri arasında dokuz sure nâzil olmuştur. Bunlar: Nisâ-4, Mâide-5, Nûr-24, Ahzâb-33, Fetih-48, Hadîd-57, Mümtehine-60, Münâfikûn-63, Talâk-65.

d) Hicretin dokuzuncu ve onuncu yıllarında da şu dört sure nâzil olmuştur: Tevbe-9, Hucurât-49, Tahrîm-66, Nasr-110. (Doğrul 1980: XLVIXLVII).

Ömer Rıza Doğrul'un yaptığı bu tasnif, bilinen sıralamadan farklı bir liste ortaya koymaktadir.

\section{Ebu'l- A’lâ el-Mevdûdî}

Benzer diğer bir çalışmayı da Ebû'l-A'lâ el-Mevdûdî'nin yaptığını görüyoruz. Mevdûdî, nüzul sürecini iki farklı yaklaşımla dönemlere ayırmaktadır. Birincisi el-Mebâdiu'l-Esâsiyye li-Fehmi'l-Kur'ân adlı eserinde risalet dönemini Hz. Peygamber ve muhatapları açısından değerlendirerek Mekke dönemini iki, Medine dönemini ise üç aşamada inceler. Mevdûdî bu eserinde

9 Ebû'l-A'la el-Mevdûdî, 3 Recep 1321'de (25 Eylül 1903) Hindistan'ın Haydarabad eyaletine bağlı Evrengabad kasabasında doğmuştur. Mevdûdî, sayısı altmışı aşan ve her biri Müslümanlar üzerinde büyük etki gösteren birçok esere imza atmıştır. Bunlar arasında Tefhîmu'l-Kur'ân'l, önemli bir yere sahiptir. Mevdûdî, 22 Eylül 1979'da New York Buffalo'da vefat etmiştir. Nâşı Pakistan'a götürülerek 1 milyondan fazla insanın katıldığ cenaze namazının ardından Lahor'daki evinin bahçesine defnedilmiştir.(26 Eylül 1979). Bkz. Burhan Çonkor, Tefhîmu'lKur'ân'da İsrâiliyyatın Ele Alınış Biçimi, (Yüksek Lisans), Selçuk Üniversitesi Sosyal Bilimler Enstitüsü, Konya, 2008, s. 7-10. 


\section{6 •SURELERIN BELIRLİ DÖNEMLERE VE OLAYLARA İZÂFESİ}

sadece dönemlere vurgu yapmıs, dönemlerle ilgili ayet ve surelere değinmemiştir. İkincisi ise Tefhîmu'l-Kur' ân ${ }^{10}$ adlı tefsirindeki yaklaşımıdır. Bu eserde Mevdûdî, Mekke dönemini dört aşamada inceler ve her aşamanın öne çıkan özelliklerini belirtir.

Sureleri Mushaf tertibine göre sıralayıp tefsir etmesine rağmen, her surenin başlangıcında "Nüzul Zamanı" adıyla bir başlık açar ve o sure ile ilgili tarihi bilgilere yer verir. Nüzul zamanı ve yeri hakkında elimize ulaşan rivayetleri değerlendiren Mevdûdî, daha sonra surelerin içerik ve üslubunu dikkate alarak bu rivayetlerin doğruluğunu ve surenin inmiş olabileceği zamanı tartışmaktadır. Ona göre nüzul zamanına dair bilgi, surelerin metinleri ve bu metin ve manaların içlerinde gizli olan delilleri incelemekle elde edilir. (Mevdûdî 2002: I/529). Risaletin Mekke yıllarını dönemlere bölüp, sureleri bu dönemlere yerleştirerek içeriklerini ilgili dönemin olayları doğrultusunda yorumlamak öncelikli olarak Batılı araştırmacıların kullandığı bir yöntem olsa da Mevdûdî, bu yöntemi kullananlar arasındadır. O, surelerin tasnifini, rivayetler ve tarihî verilerle sure muhtevalarını karşılaştırarak yapmışıı. Mevdûdî’nin, İbn Abbâs ve Câbir b. Zeyd'den nakledilen, surelerin nüzul sırasına ilişkin rivayetleri ${ }^{11}$ değerlendirmelerinde dikkate aldığ 1 görülmektedir. Mesela bu s1ralamalarda Tâhâ-Vâkıa-Şuarâ surelerinin, Şuarâ-Neml-Kasas surelerinin ve Zümer ile Mü'min suresinin peş peşe indirildikleri ifade edilmiş Mevdûdi de bu rivayetleri esas almıştır. (Mevdûdî 2002: IV/85, 153; V/125). Buna göre bu surelerden birinin diğerine önceliğini belirlemede ilgili rivayetlerden faydalandığını görmekteyiz. Dikkatimizi çeken bir diğer husus da Mevdûdî’nin, Mekkî olduğu bilinen surelerin Medenî olduğuna dair rivayetlere temkinli yaklaşmasıdır. O, birçok surede ihtilafa sebep olan, Medenî olduklarına dair rivayetleri, genellikle surenin Mekke'de indirilmesine rağmen, Medine'de ikinci kez gündeme gelmesi olarak yorumlamaktadır. İlgili yerlerde bu konu-

10 Mevdûdî'nin yazdığı eserler arasında en önemlisini Tefhîmu'l-Kur'ân teşkil eder. 1942 yılında başladığı tefsir çalışmasını, 1972 yılında tamamlamıştır. 30 yıl 4 ay gibi geniş bir zamanın ürünü olan bu eser İslam Hukuku, Târih, Akide, İslam öncesi Arap toplumlarının yaşamı, peygamberlerin hayatı ve birçok güncel içtimai-politik konuları içermektedir. Tefsir, kısa zamanda İngilizce, Arapça, Bengalce, Peştuca ve Türkçe'ye tercüme edilmiştir. (Detaylı bilgi için bkz. Anis Ahmad, "Mevdûdî", DİA, XXIX, 433-435; Çonkor, a.g.t. s. 12-13).

11 İlgili nüzul siralamaları için bkz. Ebu'l-Abbâs Ahmed b. Ebî Ya'kûb el-Ya'kûbî, Târîhu'l-Ya'kûbî, Thk. Abdulemir Mühennâ, Beyrut, 2010, I/352-353; Ebu'lFerec Muhammed b. İshâk İbnü'n-Nedîm, el-Fihrist, Thk, İbrâhîm Ramazan, Dâru'l-Ma'rife, Beyrut, 1417, s. 42-43; Suyûtî, el-İtkân, I/42-44, 96-97. 
yu gündeme getirmiştir. Örnek olarak tefsirinde; Kevser, İhlâs, Felâk ve Nâs sureleri hakkındaki değerlendirmelerine bakılabilir.

Mevdûdî, yöntem olarak Mekkî sureleri, surelerin içerdiği konuları ve rivayetleri esas alarak dört döneme ayırmaktadır. Bu dönemler ve belirlenmesine esas olan kriterler şu şekildedir:

Birinci Dönem: (İlk 3 y1l). Bu dönem, Hz. Peygamber'e risalet görevinin verilmesinden üç yıl sonra peygamberliğin açıkça ilan edilmesine kadardır. Bu dönemde vahiy, gizli olarak bazı seçkin kimselere ulaştırılmış ve genelde Mekke halkının bundan haberi olmamıştır.

Döneme ait bu bilgilerden hareketle Mevdûdî’ye göre ilk dönemde inen sureler şunlardır: Alak (1-5), Müddessir (1-7), İnsân, Fâtiha, Kalem, Mesed, Tekvîr, Â'lâ, Leyl, Duhâ, İnşirâh, Asr, Âdiyât, Kevser, Tekâsür, Fil, Kureyş, Felâk, Nâs, İhlâs, Abese, Kadir, Şems, Tîn, Kâria, Zilzâl, Kıyâme, Hümeze, Mürselât, Ğâşiye, Nûh, Mülk, Hâkka, Me’âric, Nebe, Nâziât, İnfitâr, İnşikâk, Mutaffifîn.

İkinci Dönem: (4. ve 5. yıllar). Peygamberliğin açıkça ilanıyla başlayıp iki yıl sürer. Bu dönem, bireysel karşı çıkışlarla başlar ve yavaş yavaş düşmanlık, alay, eğlence, suçlama, kötü sözler söyleme ve daveti engellemeye yönelik propaganda şeklini alır. Sonraları çoğunlukla yoksul ve zayıf Müslümanlara işkenceler yapılmaya başlar.

Buna göre ikinci dönemdeki sureleri de şu şekilde sıralamak mümkündür: Rahmân, Müzzemmil (1-19), Alak (6-19), Müddessir (8-56), Târık, Kâf, Zâriyât, Kâfirûn, Sebe', Fecr, Sâd, Tûr.

Üçüncü Dönem: (5. ve 10. y1llar). İşkencelerin başlamasından, Hz. Hatice ve Ebû Tâlib'in vefatına (hüzün y1l1-10. yıl) kadar sürer. Bu dönem, Müslümanlara yapılan işkencelerin şiddeti artmış ve bir çok Müslüman Habeşistan'a hicret etmek zorunda kalmıştır. Hz. Peygamber ve aile üyelerine karşı sosyal ve ekonomik boykot uygulanmış ve Mekke'de kalan Müslümanlar Şi'bu Ebî Tâlib'te kuşatma altına alınmıştır.

Mevdûdî’ye göre üçüncü dönem sureleri de şu şekildedir: Burûc, Beled, Kamer, Necm, Cin, Yâsîn, Furkân, Fâtır, Meryem, Tâhâ, Vâkıa, Şuarâ, Neml, Kasas, Sâffât, Lokmân, Zümer, Mü'min, Fussilet, Şûrâ, Zuhruf, Duhân, Câsiye, Kehf, Enbiyâ, Mü’minûn, Secde, Rûm, Ankebût. 
Dördüncü Dönem: (10. ve 13. yıllar). Bu dönem, Peygamberliğin 10. y1lından 13. y1lına (hicrete) kadar üç yıl sürmüştür. Bu, Hz. Peygamber ve inananlar için zorlu sınavların ve elem verici işkencelerin yaşandığı dönemdir. Mekke'de hayat çekilmez hale gelmiş, bu nedenle Hz. Peygamber Taif'e gitmiş, kendisine ne sı̆̆ınma hakkı ne de koruma sözü verilmiştir. Bunun yanı sıra peygamber, hac döneminde her Arap kabilesine daveti tebliğ etmiş, kendisine çoğunlukla olumsuz karşılık verilmiştir. Aynı zamanda Mekke halkı; ya öldürerek, ya tutuklayarak, ya da Mekke'den çıkararak kendisinden kurtulmak için girişimlerde bulunuyorlardı. İşte bu en kritik zamanda Allah (c.c), Medine'de Ensar'ın kapılarını İslâm'a açmış ve Hz. Peygamber (s.a.s) buraya hicret etmiştir. (Mevdûdî 2002: I/529-530)

Mekke döneminin son yılları olan bu dördüncü dönemdeki sureler ise şunlardır: Ahkâf, Nahl, İbrâhîm, A'râf, İsrâ, Yûnus, Hûd, Yûsuf, Ra'd, Hicr, En'âm, Hac (1-24.ayetler $\left.{ }^{12}\right)$.

Mevdûdî, sureleri dönemlere göre ayırma fikrini, En'âm suresinin girişinde anlatmış ve sonra gelen bütün Mekkî surelerin bu dönemlerden hangilerine tekabül ettiğini, her surenin girişinde açıklamıştır. Ancak bazı surelerin nüzul zamanlarına dair kesin bir tespit yapmadığı, sureleri belirttiği bu dönemlerden herhangi birine net olarak yerleştiremediği, sadece Mekkî veya Medenî olduğunu ifade ettiği de görülmektedir. (Mevdûdî 2002: VI/495-496, VII/183). Bunun yanı sıra her sure ile ilgili kısmen de olsa nüzul zamanı değerlendirmesi yapmış olmasına rağmen, bütün sureleri içeren bir kronolojik sıralama yapmadığı da dikkat çekmektedir. Surelerin nüzul zamanıyla ilgili yorumları, sıra belirleme amacından ziyade, dönem belirlemeye yöneliktir. Biz, yukarıda Mevdûdî’nin belirlediği dönemlere sureleri yerleştirirken, onun yorumlarını, surelerin sırasını belirlerken de klasik nüzul sıralamasındaki durumlarını dikkate almaya çalıştık.

Mevdûdî’nin, dönemleri tespit ederken, gerek Müslüman kesim gerekse müşrik tarafın hareketlerindeki değişimleri, davranışlardaki olumlu ve olumsuz manadaki artıp eksilmeleri dikkate aldığını görüyoruz. Yine dönemleri ayırma kriteri olarak belirlediği olayların, toplumun çoğunluğuna etki eden daha kapsamlı olaylar olduğu göze çarpmaktadır. Mekke'deki müşrik grubun, Müslümanlar üzerinde yaptığı baskının sürekli artarak devam etti-

12 Mevdûdî, Hac suresinin geri kalan 25. ayetten 78. ayetine kadar olan kısmının, gerek üslubu gerekse ele aldığı konuları göz önünde bulundurarak Medine döneminin ilk yıllarında indiğini ifade eder. (Bkz. Mevdûdî, a.g.e. III/339-340). 
ği düşüncesiyle hareket eden Mevdûdî, bilinen nüzul sıralamasında Mekke döneminin ortalarına tekabül eden bazı surelerin (Hûd, Yûnus, Yûsuf, Hicr, En'âm, A'raf) içeriklerindeki şiddet ve sert üsluplarını dikkate alarak Mekke döneminin sonlarında indiğini ifade eder. Ona göre Müslüman olanların sayısı arttıkça, özellikle Hz. Hamza ve Hz. Ömer' in Müslüman olmalarının ardından, müşriklerin uyguladığı baskı ve şiddet de artarak devam etti. (Mevdûdî 2002: V/171-175). Buna göre Mekke döneminin başlarında ve ortalarında Müslümanlara uygulanan işkencenin daha hafif olduğu düşüncesi oluşsa da köle ve kimsesizler başta olmak üzere ilk Müslümanlara yapılan acımasız işkencelerin sonrakilere yapılanlardan daha hafif olduğunu düşünmek zordur. Ancak Müslümanlara yapılan baskı ve işkencelerin, sonraki zamanlarda daha sistemli ve toplumsal bir hal aldığ düşünülebilir.

\section{Muhammed Âbid el-Câbirî}

Bir diğer araştırmacı Muhammed Âbid el- Câbirî’ dir. ${ }^{13}$ Câbirî, Fehmu'lKur'âni'l-Hakîm; Tefsiru'l-Vâdıh Hasebe Tertibi'n-Nüzûl ${ }^{14}$ adlı eserinde, Mevdûdî'den farklı olarak sureleri nüzul sırasına göre tefsir etmiş, yöntem olarak Mevdûdî’ye benzer şekilde sure içerikleri ile dönemin olayları arasında bağlantılar kurarak nüzul sürecini dönemlere ayırmıştır. Buna göre nüzul sürecine paralel olarak surelerin hem dizilişi hem de konuların bağlantılarını dikkate alarak değerlendirmelerde bulunmuştur. Yine sure içerisinde yer alan farklı konuları, başlıklar vererek birbirinden ayırmış, İslami gelenekte tartışılan bazı konularda da kendi görüşlerini açıklamıştır. Câbirî surelerin bilinen nüzul sırasını esas alarak çalıştı̆̆ için, olaylarla sureler arasındaki ir-

13 Muhammed Âbid el-Câbirî, 1936 y1lında Mağrib'in (Fas) güneydoğu bölgesinde bulunan Oujda (مدج) şehrine bağlı Figuig (كئ) köyünde doğmuştur. Birçok eseri Türkçeye tercüme edilmiştir. "Arzın Merkezinde Buluşmalar" adı altında düzenlenen konferanslar çerçevesinde 17 Eylül 2006 tarihinde ülkemize gelmiş ve fikirlerini Türkiye kamuoyu ile paylaşmıştır. Birçok esere imza atan Câbirî’nin, onlarca kitabının yanında, çeşitli dergi ve gazetelerde kaleme aldığı makale ve araştırma yazıları bulunmaktadır. Eserlerinin önemli bir kısmı, Fransızca, İngilizce, İspanyolca ve Türkçe başta olmak üzere birçok dile tercüme edilmiştir. 4 Mayıs 2010'da Kazablanka şehrinde vefat etmiş̧ir. (Detaylı bilgi için bkz. Şahin Güven, "Muhammed Âbid el-Câbirî ve Fehmu'l-Kur'âni'l-Hakîm İsimli Tefsîrindeki Metodu", Bilimname, XX, 2011/1, 53-84.)

14 Vefatından önceki son çalışması olan Fehmu'l-Kur'âni'l-Hakîm; et-Tefsîru'lVâdıh Hasebe Tertîbi'n-Nüzûl isimli eseri, üç ciltten oluşmaktadır. İlk iki cildi 2008'de, üçüncü cildi ise 2009 yılında Beyrut'ta yayınlanmıştır. Muhammed Coşkun tarafindan Türkçeye çevrilmiştir. 
tibata dair yaptığı yorumlar da bu kronolojiye uygun bir seyir izlemekte ise de, bazı surelerde klasik tertibin dışına çıktığı görülmektedir. Tefsirinde esas aldığı nüzul sıralaması şu şekildedir:

\section{Mekkî sureler:}

Alak-96, Müddessir(1-10)-74, Mesed-111, Tekvîr-81, A'lâ-87, Leyl-92, Fecr-89, Duhâ-93, İnşirâh-94, Asr-103, Âdiyat-100, Kevser-108, Tekâsür-102, Mâûn-107, Kâfirûn-109, Fil-105, Felâk-113, Nâs-114, İhlâs-112, Fâtiha-1, Rahmân-55, Necm-53, Abese-80, Şems-91, Burûc-85, Tîn-95, Kureyş-106, Kâria-101, Zilzâl-99, Kıyame-75, Hümeze-104, Mürselât-77, Kâf-50, Beled-90, Kalem-68, Târık-86, Kamer-54, Sâd-38, Araf-7, Cin-72, Yasin-36, Furkân-25, Fâtır-35, Meryem-19, Tâhâ-20, Vâkı-56, Şuarâ-26, Neml27, Kasas-28, Yûnus-10, Hûd-11, Yûsuf-12, Hicr-15, En'âm-6, Sâffât-37, Lokmân-31, Sebe'-34, Zümer-39, Ğâfir-40, Fussilet-41, Şûrâ-42, Zuhruf-43, Duhân-44, Câsiye-45, Ahkâf-46, Nûh-71, Zâriyât-51, Ğâşiye-88, İnsân-76, Kehf-18, Nahl-16, İbrâhîm-14, Enbiyâ-21, Mü’minûn-23, Secde-32, Tûr-52, Mülk-67, Hâkka-69, Meâric-70, Nebe-78, Nâziât-79, İnfitâr-82, İnşikâk-84, Müzzemmil-73, Ra'd-13, İsrâ-17, Rûm-30, Ankebût-29, Mutaffifîn-83, Hac22.

\section{Medenî sureler:}

Bakara-2, Kadîr-97, Enfâl-8, Âl-i İmrân-3, Ahzâb-33, Mümtehine-60, Nisâ-4, Hadîd-57, Muhammed-47, Talâk-65, Beyyine-98, Haşr-59, Nûr-24, Münâfikûn-63, Mücâdele-58, Hucurât-49, Tahrîm-66, Teğâbun-64, Saff-61, Cum'a-62, Fetih-48, Mâide-5, Tevbe-9, Nasr-110.

Câbirî’nin yaptığı bu sıralamada bilinen nüzul sıralamasının dışına çıktığ 1 yerler şunlardır:

1. Kalem suresi 2. siradan 35. siraya

2. Müzzemmil suresi 3. sıradan 84. siraya ${ }^{15}$

3. Fâtiha suresi 5. sıradan 20. sıraya

4. İsrâ suresi 50. sıradan 86. sıraya

5. Nûh suresi 71. sıradan 66. sıraya konulmuştur.

15 Câbirî’ye göre bu sure Mekke son dönemde inmiştir. Yapılan diğer sıralamalarda bu ayrıntıya rastlamadık. 
6. Klasik sıralamada Medenî olan Rahmân, İnsân, Ra'd, Hac ve Zilzâl sureleri Mekke dönemine yerleştirilmiştir.

7. Mekke döneminde 25. sirada olan Kadir suresini de, Medine döneminde 2. sıraya yerleştirmiştir.

Câbirî sıralamada yaptığı bu değişikliklerle ilgili şu açıklamayı yapmıştır: "Şu hususa tekrar işaret edelim ki, biz değişikliği zaruri kılan rivayetler mevcut olmadıkça mevcut iniş sıralaması listesinde herhangi bir değişiklikten kaçınıyoruz." (Câbirî 2014: I/169). Dolayısıyla Câbirî’nin klasik sıralamanın dışına çıkma sebebi, surelerle ilgili rivayetler ile sure içeriklerinin uyuşmaması ve sonuçta rivayetleri değil sure içeriklerini veya sure içeriklerine uygun rivayeti dikkate almasıdır. Yine Câbirî oluşturduğu liste için üç kaynaktan yararlandığını ifade etmektedir. Bu kaynaklar: Mevcut nüzul sıralaması, ayet ve surelerle ilgili esbâb-1 nüzul rivayetleri ve surelerin kendi iç bağlamından ve birbirleri ile olan ilişkilerinden edindiği bilgilerdir (Câbirî 2014: I/145). ${ }^{16}$

Câbirî, sureleri nüzul sırasına göre dizdikten sonra Mekke dönemine ait sureleri 6 aşamada incelemiştir. Bu aşamaları, Mevdûdî gibi sadece sıra numarasıyla değil, dönemin önemli olayları ve dönemde inen surelerin ana konularını esas alarak isimlendirmiştir. (Câbirî 2014: I/15, II/7-22). İlgili dönem isimleri incelendiğinde onun, hem dönemin önemli olaylarını hem de nüzul sürecinin aşamalarını dikkate aldığı görülecektir. Belirlediği her aşamadan önce bir giriş yazmış ve her aşamanın sonunda da yine uzun bir değerlendirme yaparak ilgili dönemde yoğun olarak işlenen konulara kendi usûlüne uygun olarak bütünsel yaklaşmıştır. Câbirî’nin Mekke dönemini tasnif ettiği aşamalar ve isimleri şu şekildedir:

Birinci Aşama: "Nübüvvet, Rubûbiyet ve Ulûhiyet"

İkinci Aşama: "Diriliş, Hesap ve Kıyâmet Sahneleri”"

Üçüncü Aşama: "Şirk Eleştirisi”"

Dördüncü Aşama: "Çağrıyı Haykırma ve Kabilelerle İletişim”

Beşinci Aşama: "Muhasara ve Habeşîstan'a Hicret"

Altıncı Aşama: "Muhasara Sonrası Kabilelerle İletişimin Sürdürülmesi ve Hicret Hazırlıkları"17

16 Câbirî’nin, tefsir çalışmasında baştan sona uyguladığı yöntem ve tercihlerinin sebeplerine dair geniş açıklama için bkz. Câbirî, Fehmu'l-Kur'ân, II/501-509.

$17 \mathrm{Bu}$ aşamalar ve belirlemesine esas olan gerekçelerle ilgili detaylı bilgi için bkz. 
Câbirî bu dönemlere sureleri yerleştirirken Mevdûdî’den farklı olarak bazı sureleri pasajlara ayırmış, yerine göre bir sure içerisindeki farklı pasajları farklı dönemlere yerleştirdiği olmuştur. Onun dönemlere göre yaptığı sure tasnifi şu şekildedir:

Birinci aşamada inen sureler: Alak (1-5.ayetler), Müddessir (1-10. ayetler), Mesed (Tebbet), Tekvîr, A’lâ, Leyl, Fecr, Duhâ, İnşirâh, Asr, Âdiyât, Kevser, Tekâsür, Maûn, Kâfirûn, Fil, Felâk, Nas, İhlâs, Fâtiha, Rahmân, Necm, Abese, Şems, Burûc, Tîn, Kureyş.

İkinci aşamada inen sureler: Kâria, Zilzâl, Kıyâmet, Hümeze, Mürselât, Kâf, Beled, Alak (6-19.ayetler), Müddessir (11-56.ayetler), Kalem, Târık, Kamer.

Üçüncü aşamada inen sureler: Sâd, A’râf, Cin, Yasin, Furkân, Fâtır, Meryem, Tâhâ, Vâkıa, Şuarâ, Neml, Kasas, Yûnus, Hûd, Yûsuf.

Dördüncü aşamada inen sureler: Hicr, En'âm, Sâffât, Lokmân, Sebe'.

Beşinci aşamada inen sureler: Zümer, Mü'min, Fussilet, Şûrâ, Zuhruf, Duhân, Câsiye, Ahkâf.

Altıncı aşamada inen sureler: Nûh, Zâriyât, Ğâşiye, İnsân, Kehf, Nahl, İbrâhîm, Enbiyâ, Mü’minûn, Secde, Tûr, Mülk, Hâkka, Meâric, Nebe, Nâziât, İnfitâr, İnşikâk, Müzzemmil, Ra'd, İsrâ, Rûm, Ankebût, Mutaffifîn, Hac. ${ }^{18}$

\section{Abdulmuteâl es-Saîdî}

Abdulmuteâl es-Saîdî, ${ }^{19}$ en-Nazmu'l-Fenniyyu fi'l-Kur'ân ${ }^{20}$ adlı eserinde, Mekke dönemini üç, Medine dönemini ise dört aşamada inceler ve her aşa-

Câbirî, a.g.e. I/17, I/163, I/239, II/23, II/105, II/223.

18 Muhammed Âbid el-Câbirî Medenî sureleri dönemsel olarak değil, içeriklerini esas alarak incelemiştir. Ancak sure girişlerinde, ilgili surenin inmiş olabileceği zamana dair görüş bildirmiştir.

19 Çok yönlü bir âlim olan Abdulmuteâl es-Saîdî (1894-1966/1971), Ezher Üniversitesi'nde hocalık yapmıştır. Arap dili ve belâğâtı, hadis, felsefe ve mantık gibi alanlarda çalışmalar yapmış ve dersler vermiştir. Yirmiden fazla eseri ve çok sayıda makalesi bulunmaktadır. (Hayatı hakkında detaylı bilgi için bkz. Muhammed Receb el-Beyyûmî, en-Nahdatu'l-İslâmiyye, Beyrut, 1995, II, 199-220).

20 Bu eser Hüseyin Elmalı tarafından Edebi Mesaj Kur'an ismiyle Türkçe'ye çevrilmiştir.(Bkz. Abdulmuteâl es-Saîdî, Edebi Mesaj Kur'ân, Çev. Hüseyin Elmalı, 
mada inmesi muhtemel sureleri zikreder. Yazar bu eserde sureleri, Fatiha' dan başlayarak Nâs suresine kadar incelemiş, her surenin başında "Nüzul Tarihi ve Adı" başlığıyla, surenin ne zaman indirildiğine ve buna dair gerekçelere, nüzul sırasındaki yerine ve sureye verilen ismin sebeplerine değinmiştir. Yine "Amacı ve Tertibi" adıyla başka bir başlık açmış ve burada da surenin inişindeki gayelere ve sıralamadaki yerine dair açıklamalarda bulunmuş, önceki sure ile bağlantısına değinmiştir. Yine bu başlık altında zaman zaman ilgili surenin tek seferde ya da bölümler halinde indirildiğine dair de fikir beyan etmektedir. Sonrasında ise surede yer alan konuları başlıklar halinde ele alarak sureye dair bir konu özeti ortaya koymuştur. Müellif yaptığı bu tasnifte sureleri dönemlere ayırarak incelese de bilinen nüzul sıralamasına bağlı kalmıştır. Ona göre Mekke dönemine ait üç aşama ve bu aşamalarda nâzil olan sureler şu şekildedir;

a) Vahyin başlangıcından Habeşistan'a hicrete kadar olan aşama. $\mathrm{Bu}$ aşamada toplam 22 sure nâzil olmuştur:

Alak-96, Kalem-68, Müzzemmil-73, Müddessir-74, Fâtiha-1, Mesed-111, Tekvîr-81, A'lâ-87, Leyl-92, Fecr-89, Duhâ-93, İnşirâh-94, Asr103, Âdiyat-100, Kevser-108, Tekâsür-102, Mâûn-107, Kâfirûn-109, Fil-105, Felâk-113, Nâs-114, İhlâs-112.

Özetle ifade edecek olursak es-Saîdî’ye göre bu dönemde inen surelerde ilk inen sureden itibaren; davetin ilanı, Hz. Peygamber'in desteklenmesi, davete hazırlanması, davete başlaması, kendisine verilen görevin büyüklüğg̈ nedeniyle Allah'a hamd etmesi, müşrikleri azapla uyararak hesaba çekileceklerini haber vermesi, mükâfat ve cezalar konusunda uyarılar yapılması gibi hususlar yer almakta ve bütün bunlar surelerin ilk dönem surelerden olduğunu göstermektedir.

b) Habeşistan'a hicretten İsrâ olayına kadar olan aşama. Bu aşamada 27 sure nâzil olmuştur:

Necm-53, Abese-80, Kadîr-97, Şems-91, Burûc-85, Tîn-95, Kureyş-106, Kâria-101, Kıyame-75, Hümeze-104, Mürselât-77, Kâf-50, Beled-90, Târık-86, Kamer-54, Sâd-38, Araf-7, Cin-72, Yasin-36, Furkân-25, Fâtır-35, Meryem-19, Tâhâ-20, Vâkıa-56, Şuarâ-26, Neml-27, Kasas-28.

Es- Saîdî bu dönem surelerde; inanç esaslarının duyurulduğunu, teşvik ve korkutma (terğîb-terhîb) üslubunun kullanıldığını, müşrik muhatapların orta- 
ya attığı şüphelere dair cevapların yer aldığını ve bu konuların, ilgili döneme uygun olduğunu zikretmektedir.

c) İsrâ olayından hicrete kadar olan aşama. Bu aşamada toplam 37 sure nâzil olmuştur:

İsrâ-17, Yûnus-10, Hûd-11, Yûsuf-12, Hicr-15, En'âm-6, Sâffât-37, Lokmân-31, Sebe'-34, Zümer-39, Ğâfir-40, Fussilet-41, Şûrâ-42, Zuhruf-43, Duhân-44, Câsiye-45, Ahkâf-46, Zâriyât-51, Ğâşiye-88, Kehf-18, Nahl-16, Nûh-71, İbrâhîm-14, Enbiyâ-21, Mü' minûn-23, Secde-32, Tûr-52, Mülk-67, Hâkka-69, Meâric-70, Nebe-78, Nâziât-79, İnfitâr-82, İnşikâk-84, Rûm-30, Ankebût-29, Mutaffifîn-83.

Es-Saîdî, bu dönem surelerle ilgili olarak; İsrâ olayının etkisinden ve bu olayın Medine'ye hicret için işaret olduğundan bahseder. Ona göre bu dönem surelerde müşriklerin yakın bir azapla uyarılmasından ve onlara meydan okunmasından bahsedilmesi, dönemde yaşananlarla sure içerikleri arasındaki uyumu da göstermektedir.

Es-Saîdî’ye göre Medine dönemine ait aşamalar ve bu aşamalarda nâzil olan sureler ise şu şekildedir:

a) Medine'ye hicretten Bedir gazvesine kadar olan aşama. Bu aşamada 1 sure nâzil olmuştur:

Bakara-2

b) Bedir savaşından Hudeybiye barışına kadar olan aşama. Bu aşamada 3 sure nâzil olmuştur:

Enfâl-8, Âl-i İmrân-3, Ahzâb-33.

c) Hudeybiye barışından Tebûk savaşına kadar olan aşama. Bu aşamada 22 sure nâzil olmuştur:

Mümtehine-60, Nisâ-4, Zilzâl-99, Hadîd-57, Muhammed-47, Ra'd13, Rahmân-55, İnsân-76, Talâk-65, Beyyine-98, Haşr-59, Nûr-24, Hâc-22, Münâfikûn-63, Mücâdele-58, Hucurât-49, Tahrîm-66, Teğâbun-64, Saf-61, Cum‘a -62, Fetîh-48, Mâide-5.

d) Tebûk savaşından Hz. Peygamber'in vefatına kadar olan aşama. Bu aşamada 2 sure nâzil olmuştur:

Tevbe-9, Nasr-110. ${ }^{21}$

21 Abdulmuteâl es-Saîdî’nin bu tasnifi ve gerekçeleri hakkında detaylı bilgi için bkz. es-Saîdî, en-Nazmu'l-Fenniyyu fi 'l-Kur'ân, Mektebetü'l-Âdâb, Kâhire, 1992, s. 


\section{Diğer Çalışmalar}

Bunların dışında günümüzde surelerin daha özel manada dönemsel olarak incelenip sure içeriklerinin tarihî sürece uygun olarak izah edildiği çalışmalar da yapılmıştır. Bunlar arasında bizim ulaşabildiklerimiz şunlardır;

1. Hatice Merve Çalışkan, M. 615 Yllında İnen Ayetler, (Yüksek Lisans), Ankara Üniversitesi Sosyal Bilimler Enstitüsü, Ankara, 2014: Bu tezde miladi 615 yılında inen surelerin tespiti yapılmaya çalışılmıştır. İlgili rivayetler ve çalışmalardan da istifa edilerek 615 yılında şu surelerin indiği ifade edilmiştir: Cin, Yasin, Furkân, Fâtır, Meryem, Tâhâ.

2. Abdülvahid Yakub Sipahioğlu, Boykot Döneminde Nâzil Olan Surelerin Tespiti Ve Değerlendirilmesi, (Yüksek Lisans), Ankara Üniversitesi Sosyal Bilimler Enstitüsü, Ankara, 2014: Bu tezde de Müşriklerin, Müslümanlar üzerindeki baskılarının arttığı ve Müslümanlara boykot uygulandığg 1616 619 tarihleri arasında inmesi muhtemel sureler tespit edilmeye çalış1lmıştır. Buna göre, boykotun başladığı miladi 616 tarihininde, yani boykot sürecinin hemen öncesinde Zümer suresinden önce indiği görülen Vâkıa, Şuarâ, Neml, Kasas, Yûnus, Hûd, Yûsuf, Hicr, En'âm, Sâffât, Lokmân ve Sebe' surelerinin indiği sonucuna varılırken, 616-619 tarihleri arasında ise şu surelerin indiği ifade edilmiştir: Mü’min, Fussilet, Şûrâ, Zuhruf, Duhân ve Câsiye. (Sipahioğlu 2014: 78-93).

3. Burhan Çonkor, Boykotun Bitiminden Hicrete Kadar Olan Dönemde İnen Surelerin Tahlili, (Doktora), Ankara Üniversitesi Sosyal Bilimler Enstitüsü, Ankara, 2015: Mekke döneminin son üç yılında inen surelerin tespit ve tahlilinin yapıldığı bu çalışmada, ilgili dönem aralığında yirmi üç surenin indirilmiş olabileceği sonucuna ulaşılmıştır. ${ }^{22}$

4. Benzer bir çalışma da Medine dönemi ile ilgili yapılmıştır. Esra Gözeler, Kur'ân Ayetlerinin Tarihlendirilmesi Sorunu ve Kur'ân'a KronolojikOlgusal bir Yaklaşım (1Rebiu'l-Evvel 4 Rebiu'l-Evvel Arası),(Doktora), Ankara Üniversitesi Sosyal Bilimler Enstitüsü, Ankara, 2009: Bu çalışmada ise hicretten sonraki ilgili tarih aralığında nâzil olan ayetlerin kronolojik olarak muhtemel sırasının belirlenmesine çalışılmıştır.

32 vd. Ayrıca müellifin bu tasnifi hakkında daha geniş değerlendirmeler için bkz. Mustafa Ünver, Tefsir Usulünde Mekkî-Medenî İlmi, (Doktora), Ondokuz Mayıs Üniversitesi Sosyal Bilimler Enstitüsü, Samsun, 1998, s. 92 vd.

$22 \mathrm{Bu}$ üç çalışma, Ankara Üniversitesi İlahiyat Fakültesi Temel İslam Bilimleri/ Tefsir Anabilim Dalı Başkanı Prof. Dr. Halis Albayrak’ın danışmanlığında hazırlanmıştır. 
5. Hadiye Ünsal, Erken Dönem Mekkî Surelerin Muhteva Tahlili, (Doktora), Çukurova Üniversitesi Sosyal Bilimler Enstitüsü, Adana, 2014: Bu çalışmada ise ilk vahiy ve erken dönem Mekkî sureler üzerinde durulmuştur.

\section{Sonuç}

İlgili çalışmalarda ortaya konan sonuçlar birbirine göre azımsanamayacak ölçüde farklılıklar arz etse de her araştırmacının kendine ait bir yöntemi ve delilleri olduğu bilinmelidir. Dolayısıyla her çalışma ile ilgili değerlendirme o çalışma bizzat incelenerek yapılmalıdır. Ortaya çıkan bu farklı sonuçlar üç temel sebebe dayandırılabilir:

a. Nüzul sebebi olarak nakledilen birden fazla rivayet arasında her araştırmacının farklı tercihte bulunması,

b. Rivayetler üzerinden geliştirilen yorumların araştırmacılara göre değişiklik arz etmesi, ${ }^{23}$

c. İnişine dair herhangi bir sebeb-i nüzûl rivayeti bulunmayan surelerin, içeriklerinden yola çıkarak dönem tespiti yapılması ve her araştırmacının yorumunun farklı olmasıdır. İctihada dayalı bu tasnif, sonuçta bu şekilde farklı bir tablo ortaya çıkarmaktadır.

Yaptı̆̆ımız araştırmanın sonucunu toplu olarak görebilmek için birkaç şemada mütalaaya sunacağız. Müelliflerin bazıları, ilgili dönemlere ait net bir tarihlendirme yapmamışlardır. Aşağıdaki tabloda yer alan tarihler, müelliflerin olaylar ve yıllarla kurduğu bağlantılar ve atıflar dikkate alınarak taraf1mızdan tahmini olarak verilmiştir. Yine bu eserlerin bazılarında, aynı dönemde inen surelerin kendi içerisindeki tertibine dair birkaç sure dışında bilgiye rastlanmaz. Biz bu sıralamayı yaparken, sureyi müellifin belirttiği döneme yerleştirdikten sonra ilgili surelerin dönem içindeki sırasını, bilinen nüzul sıralamasındaki birbirine göre yerlerini dikkate alarak yaptık. Şunu da belirtmek gerekir ki, dönemlerin başları ve sonları kesin bir çizgi ile ayrılamadığından, aynı yorumu yapan müelliflerin, sureleri farklı dönemlere yerleştirdiği de olmuştur. Bu açıdan bizim bu değerlendirmelerde dikkate aldığımız husus, müelliflerin yıllara göre değil, olaylara göre kurdukları bağlantılar olmuştur.

23 Örneğin bir sure ile ilgili rivayet edilen ve tarihi bildirilmemiş bir olayın, ne zaman meydana geldiği konusunda her araştırmacının farklı bir zaman tespitinde bulunmasi. 


\begin{tabular}{|c|c|c|c|}
\hline \multirow{8}{*}{ 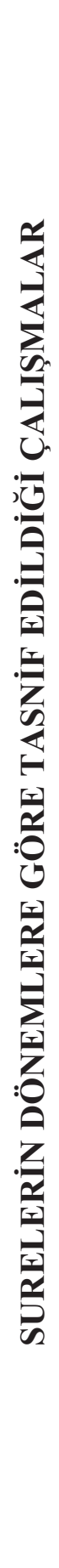 } & $\therefore \frac{\widehat{c}}{\frac{1}{3}}$ & 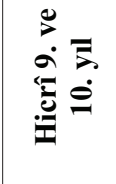 & 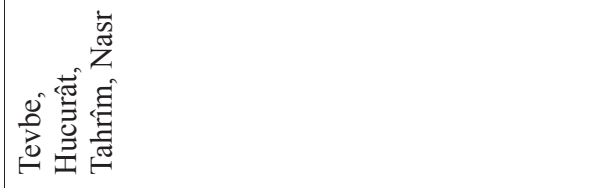 \\
\hline & 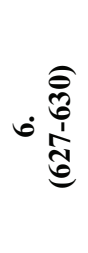 & 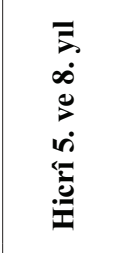 & 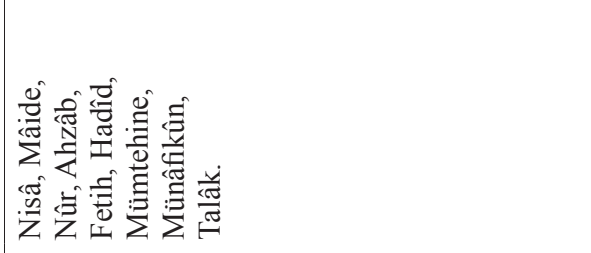 \\
\hline & 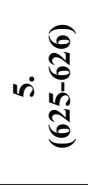 & 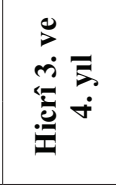 & 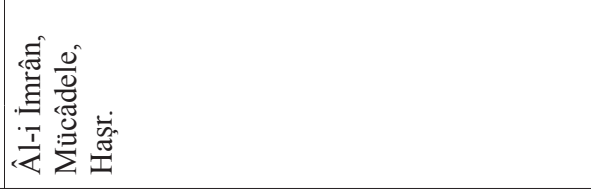 \\
\hline & 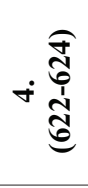 & 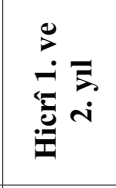 & 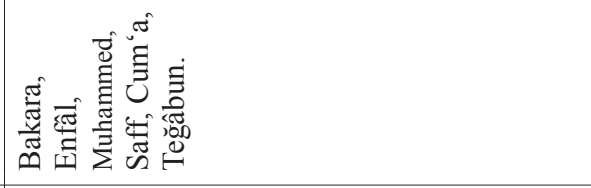 \\
\hline & ri ָั & 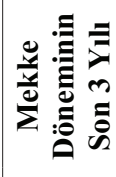 & 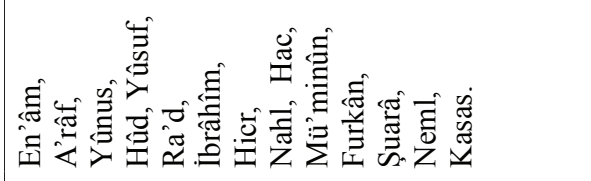 \\
\hline & i $\frac{\sigma}{\frac{2}{0}}$ & 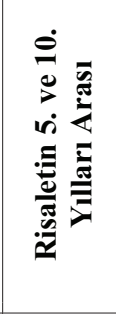 & 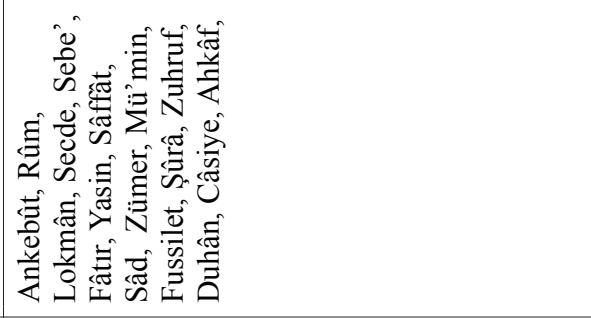 \\
\hline & $-\frac{\int}{\frac{J}{0}}$ & 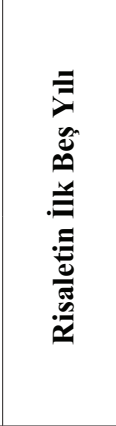 & 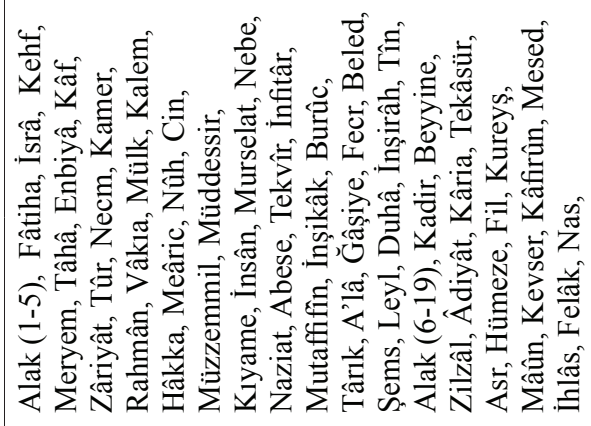 \\
\hline & & & 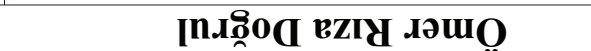 \\
\hline
\end{tabular}


148 •SURELERİN BELİRLİ DÖNEMLERE VE OLAYLARA İZÂFESİ

\begin{tabular}{|c|c|c|}
\hline 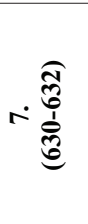 & 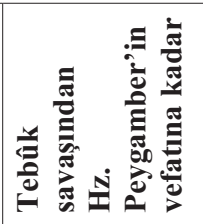 & 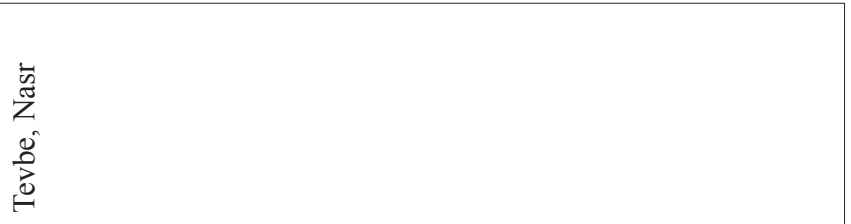 \\
\hline 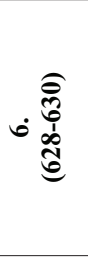 & 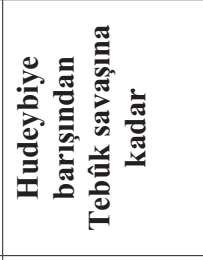 & 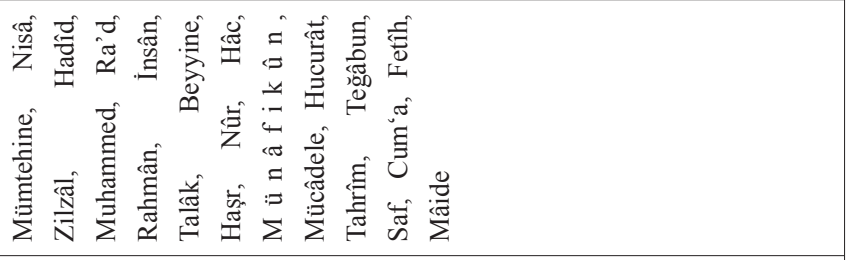 \\
\hline 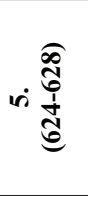 & 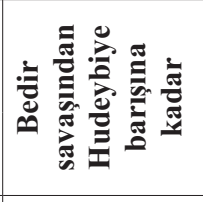 & 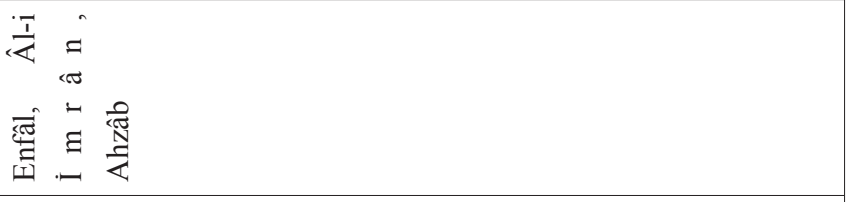 \\
\hline 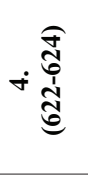 & 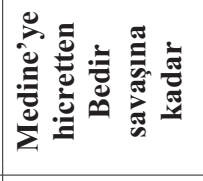 & 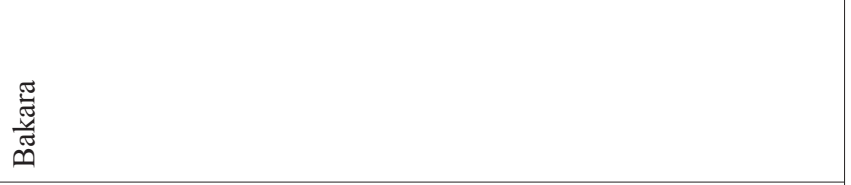 \\
\hline r & 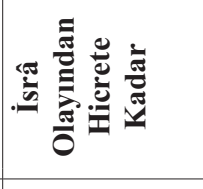 & 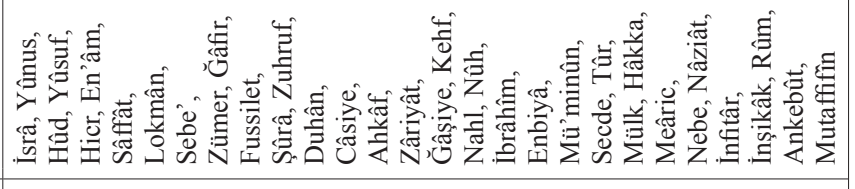 \\
\hline ن & 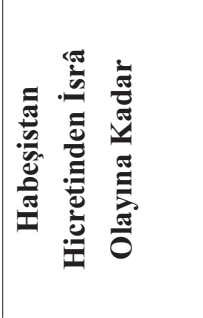 & 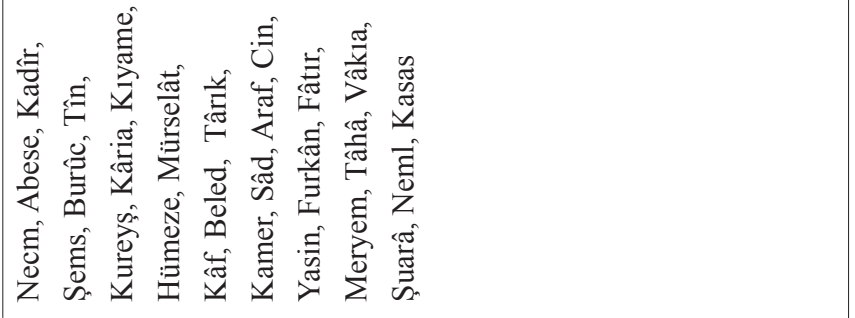 \\
\hline 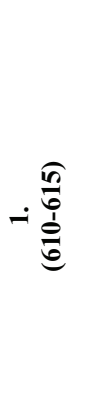 & 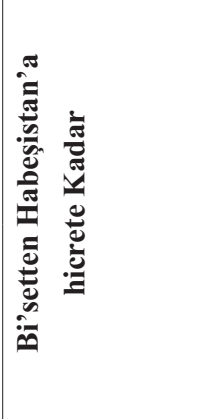 & 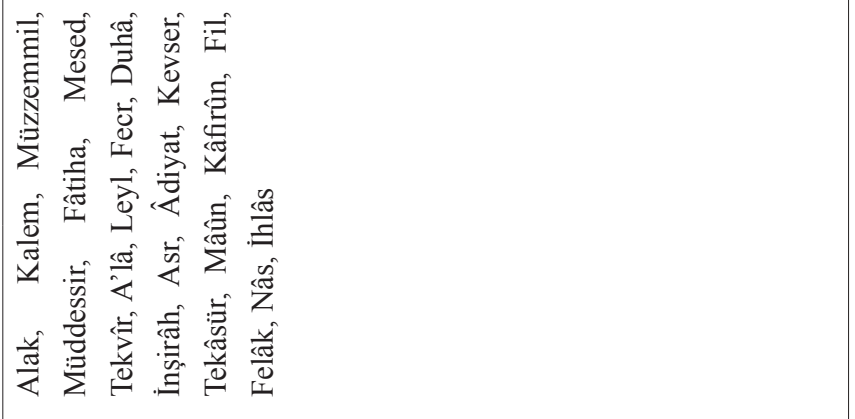 \\
\hline & & pIBS-Sə IGə†nu|npqV \\
\hline
\end{tabular}




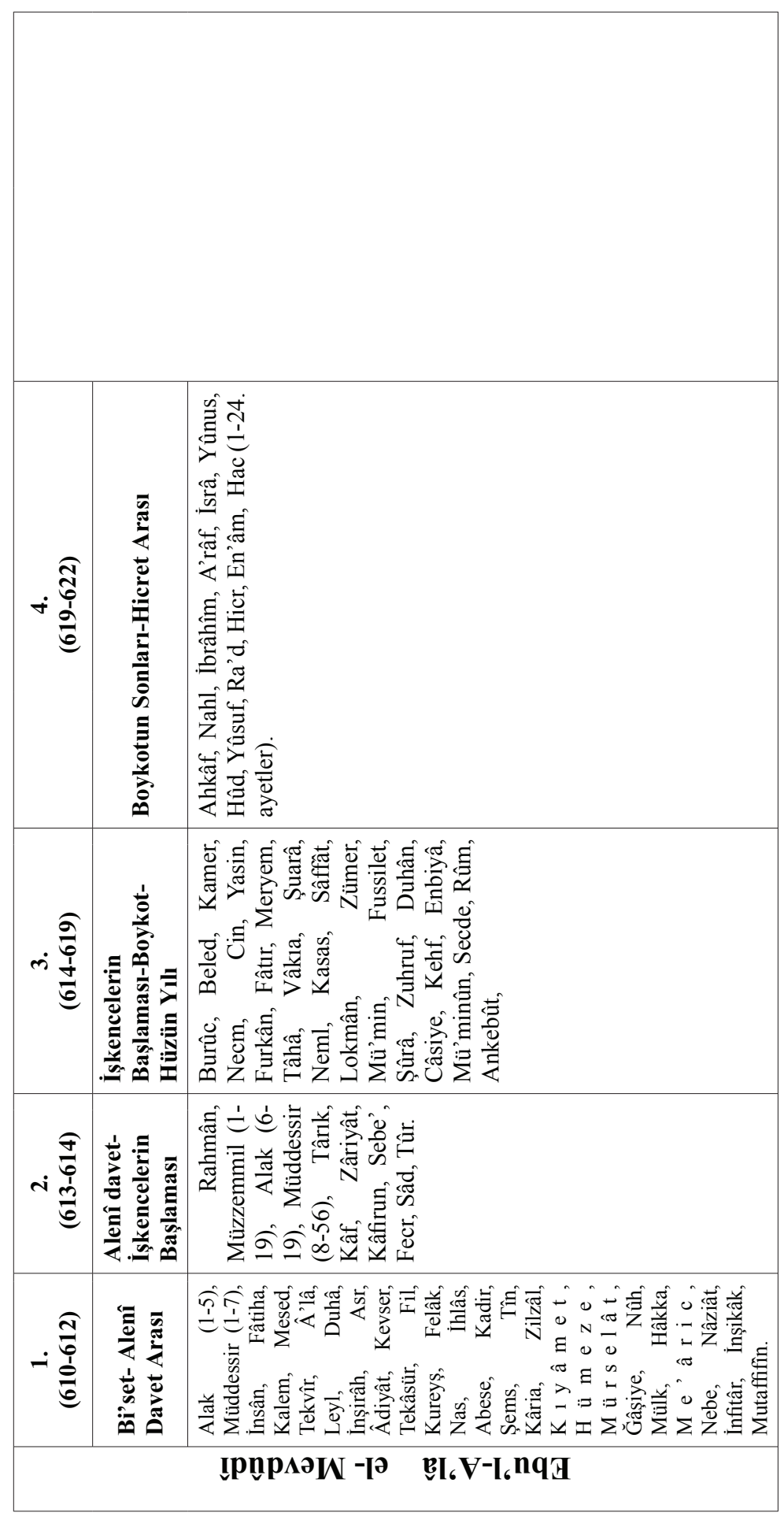


150 •SURELERİN BELİRLİ DÖNEMLERE VE OLAYLARA İZÂFESİ

\begin{tabular}{|c|c|c|}
\hline 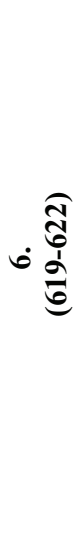 & 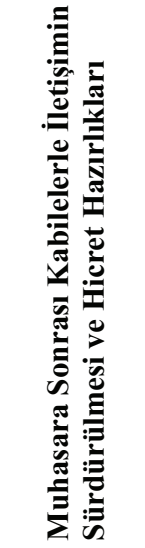 & 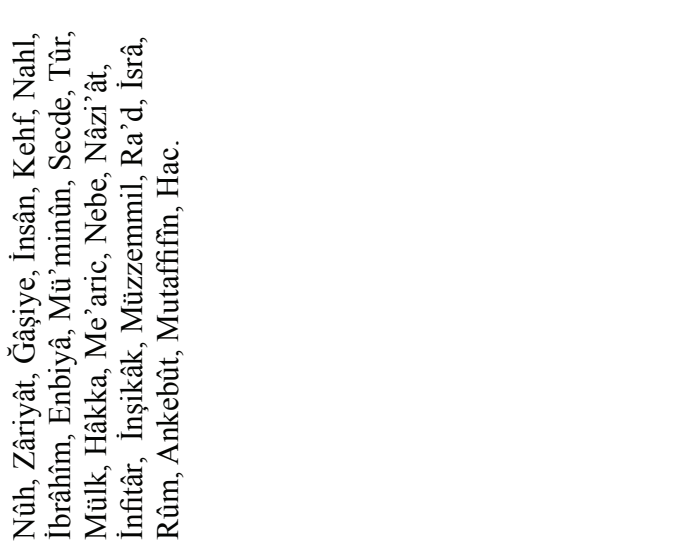 \\
\hline in $\frac{\hat{\sigma}}{0}$ & 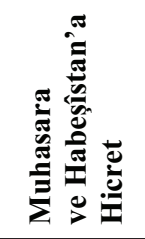 & 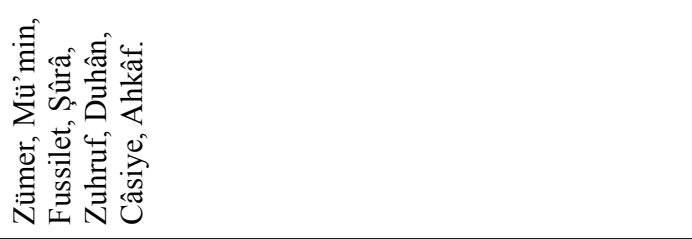 \\
\hline 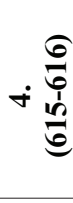 & 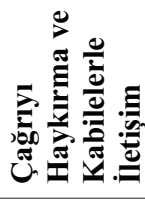 & 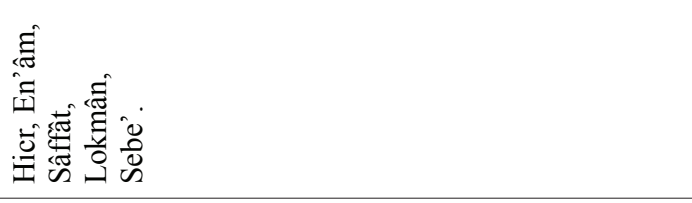 \\
\hline ri & 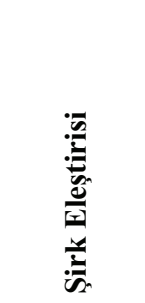 & 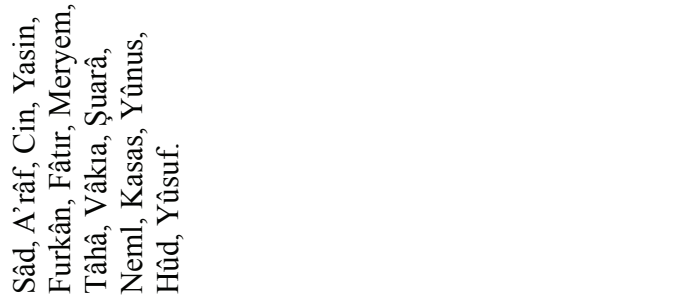 \\
\hline ن & 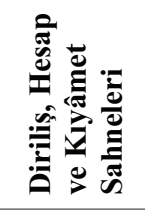 & 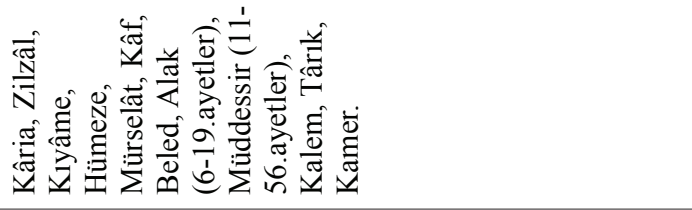 \\
\hline$-\frac{\sqrt[m]{0}}{0}$ & 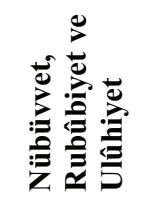 & 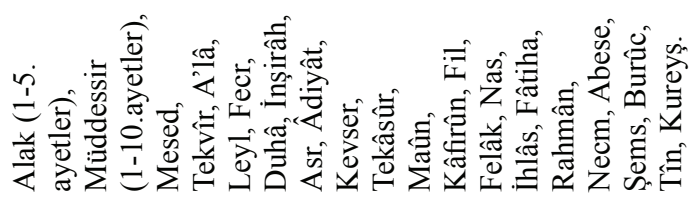 \\
\hline & & urynW \\
\hline
\end{tabular}




\section{Kaynaklar}

- Ahmad, Anis (2004), "Mevdûd̂̂", DİA, XXIX, 433-435.

- Akpınar, Ali (2007), "Çok Yönlü Bir Kişilik Olarak Ömer Rıza Doğrul (18931952)", I. Burdur Sетроzуити, Burdur, s. 439-447.

- —_, (2010), “Tanrı Buyruğu”, DİA, XXXIX/571-572.

- Albayrak, İsmail (2002), "Kur’ân Âyetlerinin Tertibi Hakkındaki Oryantalist Söyleme Genel Bir Bakış", Marife, 2/3, s. 155-164.

- Beyyûmî, Muhammed Receb (1995), en-Nahdatu'l-İslâmiyye, Beyrut.

- Beyhakî, Ebû Bekr Ahmed b. Ali (1405), Delâilü'n-Nübüvve ve Ma'rifetü Ahvâli Sâhibi'ş-Şerî'a, Beyrut,

- Câbirî, Muhammed Âbid, Fehmu'l-Kur'âni'l-Hakîm: et-Tefsîru'l-Vâdıh Hasebe Tertîbi'n-Nüzûl, Beyrut, (I-II. 2008), (III. 2009).

- _ (2014), Fehmu'l-Kur'ân-Siyer Eşliğinde Kur'ân'ı Anlamak, Ter. Muhammed Coşkun, Mana Yayınları, İstanbul.

- Cerrahoğlu, İsmail (1998), Tefsir Usulü, TDV. Yay, Ankara.

- Çonkor, Burhan (2008), Tefhîmu'l-Kurân'da İsrâiliyyatın Ele Alınış Biçimi, (Yüksek Lisans), Selçuk Üniversitesi Sosyal Bilimler Enstitüsü, Konya.

- _ (2015), Boykotun Bitiminden Hicrete Kadar Olan Dönemde İnen Surelerin Tahlili, (Doktora), Ankara Üniversitesi Sosyal Bilimler Enstitüsü, Ankara.

- Doğrul, Ömer Rıza (1980), Tanrı Buyruğu-Kur'ân-ı Kerîm 'in Tercüme ve Tefsiri, İnk1lâp ve Aka Basımevi, İstanbul.

- Gözeler, Esra (2010), “Kur'ân Ayetlerinin Târihlendirilmesine Batılı Yaklaşımlar", AÜIF Dergisi, Cilt: LI sy, 2, s. 299-316.

- Güven, Şahin (2011), "Muhammed Âbid el-Câbirî ve Fehmu'l-Kur'âni'l-Hakîm İsimli Tefsîrindeki Metodu”, Bilimname, XX, s. 53-84.

- Hâzin, Alâuddîn Ali b. Muhammed b. İbrâhîm (1415), Lübâbü't-Te'vîl fi Meâni'tTenzîl, Dâru'l-Kütübi'l-İlmiyye, Beyrut.

- İbnü’n-Nedîm, Ebu'l-Ferec Muhammed b. İshâk (1417), el-Fihrist, Thk, İbrâhîm Ramazan, Dâru'l-Ma'rife, Beyrut.

- Kurt, Yaşar (2012), “Kur'ân'ın Nüzûl Süreci ve Nüzûl Sırasını Esas Alan Tefsir Üzerine", OMÜ. İlahiyat Fakültesi Dergisi, sayı, 33, s. 5-39.

- Mevdûdî, Ebû'l-A'lâ (2002), Tefhîmu'l-Kur'ân, Ter. Komisyon, İnsân yay, İstanbul.

- Polat, Fethi Ahmet (2008), Çağdaş İslam Düşüncesinde Kur'ân'a Yaklaşımlar, İz Yay. İstanbul.

- es-Saîdî, Abdulmuteâl (1992), en-Nazmu'l-Fenniyyu fi'l-Kur'ân, Mektebetü'lÂdâb, Kâhire. 
- Sipahioğlu, Abdülvahid Yakub (2014), Boykot Döneminde Nâzil Olan Surelerin Tespiti ve Değerlendirilmesi, (Yüksek Lisans), Ankara Üniversitesi Sosyal Bilimler Enstitüsü, Ankara.

- Subhi es-Sâlih (2000), Mebâhis fí Ulûmi'l-Kur'ân, Dâru'l-İlmi lilmelâyîn, Beyrut.

- Suyûtî, Ebu'l-Fadl Celâlüddîn Abdurrrahman (1974), el-İtkân fí Ulûmi'l-Kur'ân, Thk. Muhammed Ebû'l-Fadl İbrâhîm, Dâru'l-Ma'rife, Beyrut.

- Uzun, Mustafa (1994), "Doğrul, Ömer Rıza”, DİA, IX/489.

- Ünver, Mustafa (1998), Tefsir Usulünde Mekkî-Medenî İlmi, (Doktora), Ondokuz Mayıs Üniversitesi Sosyal Bilimler Enstitüsü, Samsun.

- Ya'kûbî, Ebu'l-Abbâs Ahmed b. Ebî Ya‘kūb (2010), Târîhu’lYa'kûbî, I-II, Beyrut.

- Zerkeşî, Bedreddîn Muhammed b. Abdullah (1957), el-Burhân fí Ulûmi'l-Kur'ân, Thk. Muhammed Ebû'l-Fadl İbrâhîm, Dâru'l-Ma'rife, Beyrut. 